\title{
Characterization of black carbon-containing fine particles in Beijing during wintertime
}

\author{
Junfeng Wang ${ }^{1}$, Dantong $\mathrm{Liu}^{2}$, Xinlei Ge ${ }^{1}$, Yangzhou $\mathrm{Wu}^{1}$, Fuzhen Shen ${ }^{1}$, Mindong Chen ${ }^{1}$, Jian Zhao ${ }^{3,4}$, \\ Conghui Xie ${ }^{3,4}$, Qingqing Wang ${ }^{3}$, Weiqi $\mathrm{Xu}^{3,4}$, Jie Zhang ${ }^{5}$, Jianlin $\mathrm{Hu}^{1}$, James Allan ${ }^{2,6}$, Rutambhara Joshi ${ }^{2}$, \\ Pingqing $\mathrm{Fu}^{3}$, Hugh $\mathrm{Coe}^{2}$, and Yele Sun ${ }^{3,4}$ \\ ${ }^{1}$ Jiangsu Key Laboratory of Atmospheric Environment Monitoring and Pollution Control, Collaborative Innovation Center of \\ Atmospheric Environment and Equipment Technology, School of Environmental Science and Engineering, Nanjing \\ University of Information Science and Technology, Nanjing 210044, China \\ ${ }^{2}$ School of Earth and Environmental Sciences, University of Manchester, M13 9PL, Manchester, UK \\ ${ }^{3}$ State Key Laboratory of Atmospheric Boundary Layer Physics and Atmospheric Chemistry, Institute of Atmospheric \\ Physics, Chinese Academy of Sciences, Beijing 100029, China \\ ${ }^{4}$ University of Chinese Academy of Sciences, Beijing 100049, China \\ ${ }^{5}$ Atmospheric Sciences Research Center, University at Albany, State University of New York, NY 12203, USA \\ ${ }^{6}$ National Centre for Atmospheric Science, University of Manchester, M13 9PL, Manchester, UK
}

Correspondence: Xinlei Ge (caxinra@ 163.com)

Received: 3 August 2018 - Discussion started: 31 August 2018

Revised: 19 December 2018 - Accepted: 21 December 2018 - Published: 11 January 2019

\begin{abstract}
Refractory black carbon (BC) is a product of incomplete combustion of fossil fuel, biomass and biofuel, etc. By mixing with other species, BC can play significant roles in climate change, visibility impairment and human health. Such BC-containing particles in densely populated megacities like Beijing may have specific sources and properties that are important to haze formation and air quality. In this work, we exclusively characterized the BC-containing particles in urban Beijing by using a laser-only Aerodyne soot particle aerosol mass spectrometer (SP-AMS), as part of the Atmospheric Pollution \& Human Health (APHH) 2016 winter campaign. The average mass ratio of coating to $\mathrm{BC}$ core $\left(R_{\mathrm{BC}}\right)$ was found to be $\sim 5.0$. Positive matrix factorization shows the presence of significant primary fossil fuel and biomass-burning organics (64\% of total organics). Yet secondary species, including sulfate, nitrate and oxygenated organic aerosol (OA) species, could have significant impacts on the properties of BC-containing particles, especially for ones with larger BC core sizes and thicker coatings. Analyses of sources and diurnal cycles of organic coating reveal significant afternoon photochemical production of secondary OA (SOA), as well as nighttime aqueous production of a portion of highly oxygenated OA. Besides SOA, photochemi-
\end{abstract}

cal production of nitrate, not sulfate, appeared to be important. Further investigations on BC-containing particles during different periods show that, on average, more polluted periods would have more contributions from secondary species and more thickly coated $\mathrm{BC}$ tended to associate with more secondary species, indicating the important role of chemical aging to the pollution of BC-containing particles in urban Beijing during wintertime. However, for individual pollution events, primary species (fossil fuel, coal and biomassburning emissions) could also play a dominant role, as revealed by the compositions of $\mathrm{BC}$-containing particles in two polluted episodes during the sampling period.

\section{Introduction}

Black carbon (BC) is generated from incomplete combustion of carbon-based fuels (Ramanathan and Carmichael, 2008) and can exert significant impacts on global and regional climate, planetary boundary layer height (PBLH), air quality and human health, etc. (Lee et al., 2017; Bond et al., 2013; Ding et al., 2016). BC can strongly absorb solar radiation and warm up the atmosphere directly. By internally or ex- 
ternally mixing with non-BC materials (coatings, including co-emitted primary organic/inorganic and secondary materials that associate with BC) (C. Chen et al., 2016; Lee et al., 2017; J. Wang et al., 2017), the properties and morphologies of BC might be altered greatly (Liu et al., 2013, 2015, 2017; Cappa et al., 2012; Peng et al., 2016; Y. Wang et al., 2017b; Li et al., 2016). Thick coating can increase the mass absorption cross section of $\mathrm{BC}$, thus enhance the light absorption of BC core via "lensing effect" (Jacobson, 2001; Liu et al., 2015; Pokhrel et al., 2017). However, coating thickness of BC-containing particles significantly depends on sources/chemical compositions and aging processes; thus there are great uncertainties in light absorption enhancement ( $\left.E_{\text {abs }}\right)$ of $\mathrm{BC}$ as well as its global radiative forcing (Cappa et al., 2012; Liu et al., 2015, 2017; Cui et al., 2016). For instance, the mass ratio of coatings to $\mathrm{BC}$ core $\left(R_{\mathrm{BC}}\right.$, an analog of coating thickness) from biomass burning is usually greater than 3 (Liu et al., 2017) and can be larger than 10 in remote sites (J. Wang et al., 2017). Normally, when $R_{\mathrm{BC}}$ is less than 1.5 , it is probably from traffic sources, whereas secondary organic aerosol (SOA) dominant BC-containing particles is usually with a $R_{\mathrm{BC}}$ greater than 4 (Lee et al., 2017). Moreover, the coating species can modify the hygroscopicity of BC-containing particles (Liu et al., 2013) when associated with hydrophilic materials, and some of them can be activated as cloud condensation nuclei $(\mathrm{CCN})$, therefore altering the albedo and precipitation of clouds indirectly (Dusek et al., 2010, 2006).

In the past decades, a number of field studies on $\mathrm{BC}$ have been conducted in the winter of Beijing and have mainly focused on $\mathrm{BC}$ mass loadings, mixing states, optical properties, human health impacts and sources (coal combustion, biomass burning and vehicles, etc.) (Wu et al., 2017, 2016; Cheng et al., 2017; Ji et al., 2017; Y. Wang et al., 2017a; Q. Wang et al., 2016; Y. Chen et al., 2016; Meng et al., 2016; Liu et al., 2016; Yang et al., 2014; Schleicher et al., 2013a, b; Song et al., 2013; Zhang et al., 2017). There were real-time studies on $\mathrm{BC}$ and on the chemical characteristics of total fine particles (including particles with and without BC) in Beijing. However, to the best of our knowledge, no study was conducted in real time to characterize the chemical compositions exclusively of BC-containing particles in Beijing despite the aforementioned important effects of coating materials on $\mathrm{BC}$ properties. Currently, a few studies have explored BC-containing particles in other locations, e.g., Toronto (Willis et al., 2016; Lee et al., 2015), California (Lee et al., 2017; Massoli et al., 2015; Cappa et al., 2012), London (Liu et al., 2015) and Tibet (J. Wang et al., 2017) by using the Aerodyne soot-particle aerosol mass spectrometer (SP-AMS) (Onasch et al., 2012; Lee et al., 2015; J. Wang et al., 2016; Ge et al., 2017b). The SP-AMS physically combines the $1064 \mathrm{~nm}$ laser vaporizer of single-particle soot photometer (SP2) into a high-resolution aerosol mass spectrometer (HR-AMS). After removal of the AMS tungsten vaporizer and by operating the instrument with laser vaporizer only, refractory $\mathrm{BC}$ as well as its associated coating can be evaporated, since the $1064 \mathrm{~nm}$ laser can selectively heat the BC (Massoli et al., 2015). In other words, laser-only SP-AMS can exclusively measure $\mathrm{BC}$ cores and the species coated on $\mathrm{BC}$ cores. This unique technique allows us to explore the characteristics of BC-coating species in detail with no perturbations from other co-existing non-BC containing particles in ambient air.

Beijing, as the most reprehensive megacity with a large population in developing countries, the BC-containing particles may have specific source profiles and physiochemical properties; therefore elucidation of its characteristics is important to understand the haze formation and improve air quality in such regions. In this work, as part of the UK-China Atmospheric Pollution \& Human Health (APHH) study (Shi et al., 2018), we report for the first time the real-time measurement results on the chemical composition, mass loading, size distribution and sources/processes of BC-containing particles during the wintertime of 2016 in urban Beijing. Results regarding physical properties and optical properties are presented in Liu et al. (2018) and Xie et al. (2019) of this special issue, respectively.

\section{Experiments}

\subsection{Sampling site and instrumentation}

As part of the APHH winter campaign, we conducted measurements at the Tower Division of Institute of Atmospheric Physics (IAP), Chinese Academy of Science $\left(39^{\circ} 58^{\prime} \mathrm{N}\right.$, $116^{\circ} 22^{\prime} \mathrm{E}$ ) in Beijing (Fig. S1 in the Supplement), from 15 November to 13 December of 2016. The site was surrounded by residential infrastructures and a freeway in the east (360 m).

The SP-AMS was deployed on the rooftop of the Herong building ( $\sim 8 \mathrm{~m}$ above the ground), with a $\mathrm{PM}_{2.5}$ cyclone (model URG-2000-30EN) and a diffusion dryer in front of the inlet. The single-particle soot photometer (SP2, Droplet Measurement Technology, Inc., Boulder, CO, USA) was operated simultaneously inside another container nearby $(\sim$ $20 \mathrm{~m}$ away) on the ground. The SP2 incandescence signal was calibrated for BC mass by using Aquadag ${ }^{\circledR}$ black carbon standard (Aqueous Deflocculated Acheson Graphite, Acheson Inc., USA) (Laborde et al., 2012). For the SP-AMS, since the filament that ejects electrons can still heat the tungsten vaporizer up to $\sim 200^{\circ} \mathrm{C}$ (Willis et al., 2014) even if it is turned off, the tungsten vaporizer was thus physically removed to make sure only $\mathrm{BC}$ and its associates were vaporized by the laser and to eliminate the influence of uncoated species on BC cores.

The tuning and calibration procedures of SP-AMS followed the procedures described previously (Lee et al., 2015; Willis et al., 2016; Massoli et al., 2015; J. Wang et al., 2017). During the campaign, the SP-AMS was run with a 10 min cy- 
cle: one $\mathrm{W}$ mode with high chemical resolution $(2.5 \mathrm{~min})$ and two mass sensitive $\mathrm{V}$ modes, including one with particle time of flight (PToF) mode (2.5 min) and another one $(5 \mathrm{~min})$ with a large mass-to-charge $(\mathrm{m} / \mathrm{z}$ ) range (up to 2000) (J. Wang et al., 2016). The filtered air measurement was performed for a day to determine the detection limits (DLs) of various aerosol species and to adjust the fragmentation table. The ionization efficiency (IE) and relative ionization efficiency (RIE) of sulfate and nitrate were calibrated by using pure ammonium nitrate and ammonium sulfate according to Jayne et al. (2000), respectively. RIE of BC was calibrated by using REGAL black particles (RB, REGAL 400R pigment black, Cabot Corp.) (Onasch et al., 2012), and the average ratio of $\mathrm{C}_{1}^{+}$to $\mathrm{C}_{3}^{+}$was determined to be 0.53 to minimize the influence of $\mathrm{C}_{1}^{+}$from non-refractory organics. However, it should be aware that the laser-only SP-AMS cannot vaporize ammonium nitrate or sulfate if they do not coat $\mathrm{BC}$; thus the IE and RIE calibrations were done before removal of the tungsten vaporizer and the values were assumed to be unchanged after the tungsten heater's removal (Willis et al., 2016). Note that the RIE of BC was calibrated before the campaign and was repeated in the middle and end of the campaign. RIEs of nitrate, ammonium, sulfate and $\mathrm{BC}$ were determined to be $1.1,3.82,0.82$ and 0.17 , respectively. The default value of 1.4 was used as the RIE of organics (Canagaratna et al., 2007). Polystyrene latex (PSL) spheres (100-700 nm) (Duke Scientific Corp., Palo Alto, CA) were used to calibrate the size before the campaign (Canagaratna et al., 2007) .

\subsection{Data analysis}

Standard AMS data analysis software (Squirrel and Pika) based on Igor Pro 6.37 (Wavemetrixs, Lake Oswego, OR, USA) were used to obtain the concentrations, mass spectra and size distributions of $\mathrm{BC}$ and its coating species. All data were calculated based on high-resolution fitting results. Due to different vaporization schemes between the SP-AMS and HR-AMS, the mass spectra from these two instruments even for the same population of particles are not entirely the same. Laser-only SP-AMS can result in less fragmentation overall; therefore the mass profile may contain more large $m / z$ fragments and less small $m / z$ fragments compared with that from HR-AMS (Massoli et al., 2015). Therefore, here the elemental ratios of organics, i.e., oxygen-to-carbon, hydrogen-tocarbon and nitrogen-to-carbon ratios $(\mathrm{O} / \mathrm{C}, \mathrm{H} / \mathrm{C}$ and $\mathrm{N} / \mathrm{C})$ were determined by the Aiken approach first (Aiken et al., 2008), and then $\mathrm{O} / \mathrm{C}$ and $\mathrm{H} / \mathrm{C}$ were corrected by using factors of 0.83 and 1.16, respectively (Canagaratna et al., 2015).

Source apportionment for organics coated on BC was conducted by using positive matrix factorization (PMF) (Paatero and Tapper, 1994) evaluation tool written in Igor (Ulbrich et al., 2009). In this study, high-resolution mass spectra (HRMS) of organic (including BC) and inorganic species were combined together to perform the PMF analyses (Sun et al., 2012; J. Wang et al., 2017, 2018). It should be no-

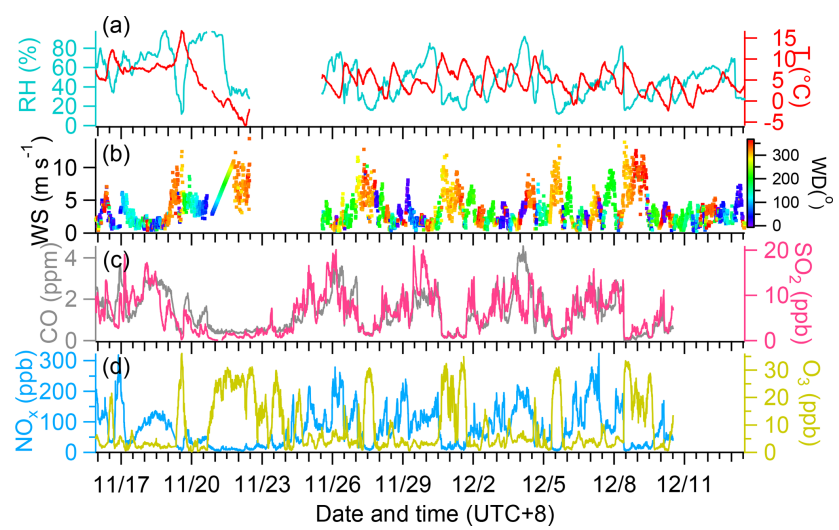

Figure 1. Temporal variation in (a) relative humidity (RH) and temperature $\left(T,{ }^{\circ} \mathrm{C}\right)$, (b) wind speed (WS, $\mathrm{m} \mathrm{s}^{-1}$ ) and wind direction (WD) and (c, d) mass loadings of $\mathrm{CO}, \mathrm{SO}_{2}, \mathrm{NO}_{x}$ and $\mathrm{O}_{3}$.

ticed that only fragment ions from polycyclic aromatic hydrocarbons (PAHs) were included for $\mathrm{m} / z$ range of $\sim 150$ to $\sim 250$ in the PMF analysis because of the limited mass resolution of SP-AMS. All PMF solutions were evaluated following the standard instruction (Zhang et al., 2011). Finally, four types of organic aerosol (OA) associated with BC were determined eventually, including a fossil fuel combustion OA (FFOA), a biomass-burning OA (BBOA) and two oxygenated OA (OOA1 and OOA2) (a diagnostic plot was provided in Fig. S2).

Supporting data such as meteorological parameters including relative humidity (RH), wind speed (WS), wind direction (WD) and temperature (T), as well as concentrations of gaseous species such as $\mathrm{O}_{3}, \mathrm{SO}_{2}, \mathrm{NO}, \mathrm{NO}_{2}, \mathrm{NO}_{x}, \mathrm{NO}_{y}$, $\mathrm{NO}_{z}$, and $\mathrm{CO}$ were measured in parallel. All data here are reported in local time (Beijing Time, UTC +8 ).

\section{Results and discussion}

\subsection{Overview of BC-containing aerosol characteristics}

Figures 1 and 2 show the temporal variations in meteorologic parameters, mass loadings of gaseous pollutants $\left(\mathrm{CO}, \mathrm{NO}_{x}\right.$, $\mathrm{SO}_{2}$ and $\mathrm{O}_{3}$ ), $\mathrm{BC}$ and its associated coating components (sulfate, nitrate, ammonium, chloride, total OA and four PMFresolved $\mathrm{OA}$ factors). The campaign-averaged composition of BC-containing particles and mass contributions of the four OA factors to total OA were also displayed in Fig. 2. Overall, wind directions and speeds had close associations with overall mass loadings of BC-containing particles. The polluted periods (characterized by concentrations of $\mathrm{BC}$-containing particles above $10 \mu \mathrm{g} \mathrm{m}^{-3}$ ) were accompanied by relatively low wind speeds $\left(<4 \mathrm{~m} \mathrm{~s}^{-1}\right)$ and in a relatively large part from southern air masses, since Beijing is at the foot of the mountains, which facilitates the accumulation of pollutants from the southern North China Plain (NCP). The 


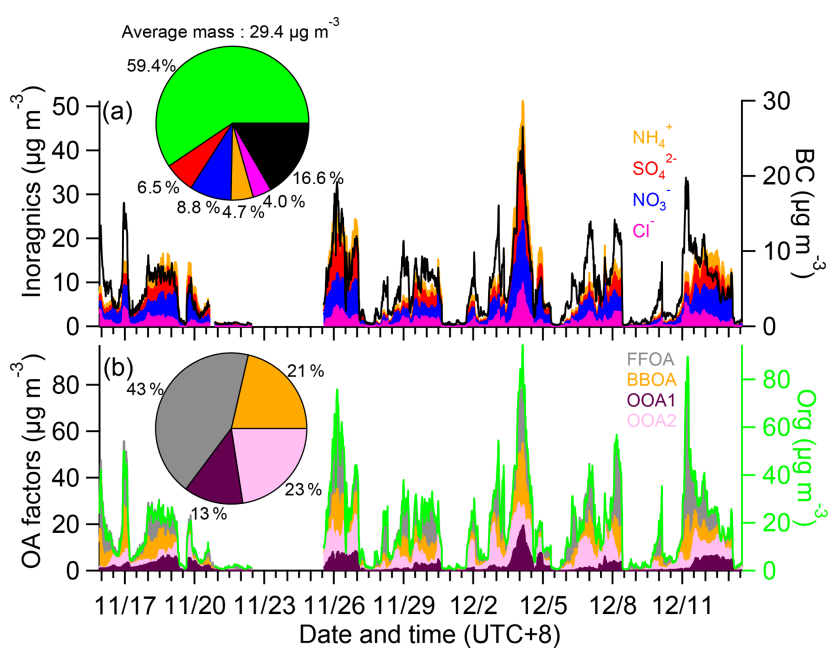

Figure 2. (a) Temporal variations in mass loadings of inorganic coating components (sulfate, nitrate, ammonium and chloride) and $\mathrm{BC}$ cores, and (b) temporal variations in mass loadings of organic coating (Org) and PMF-separated OA factors (inset pie charts show the average composition of total BC-containing particles and organics, respectively).

clean periods (characterized by the concentrations of $\mathrm{BC}$ containing particles below $10 \mu \mathrm{g} \mathrm{m}^{-3}$ ) were mainly under the control of northwesterly strong winds $\left(>4 \mathrm{~m} \mathrm{~s}^{-1}\right)$ (Fig. S3). During the campaign, the mass loadings of $\mathrm{BC}$ cores and BC-containing particles ranged from 0.11 to $26.54 \mu \mathrm{g} \mathrm{m}^{-3}$ and 0.71 to $174.40 \mu \mathrm{g} \mathrm{m}^{-3}$, with averages of $4.9 \mu \mathrm{g} \mathrm{m}^{-3}$ and $29.4 \mu \mathrm{g} \mathrm{m}^{-3}$, respectively. We also compared BC concentrations determined by the SP-AMS with those from SP2, and they correlated quite well with each other $\left(r^{2}\right.$ of 0.93 ; Fig. S4), indicating that the quantification of BC by the SPAMS is reliable.

The coating species occupied on average about $83.4 \%$ of the mass of $\mathrm{BC}$-containing particles, indicating that $\mathrm{BC}$ was generally thickly coated throughout the whole campaign, with an average mass ratio of coatings to $\mathrm{BC}\left(R_{\mathrm{BC}}\right)$ of $\sim 5.0$. Organic aerosol (OA) was the most abundant coating component, taking up $59.4 \%$ of the total mass, followed by nitrate $(8.8 \%)$, sulfate $(6.5 \%)$, ammonium $(4.7 \%)$ and chloride $(4.0 \%)$. OA correlated quite well with $\mathrm{BC}\left(r^{2}\right.$ of 0.97$)$, suggesting that many OA species were co-emitted and mixed with $\mathrm{BC}$, and indeed, primary $\mathrm{OA}$ $(\mathrm{POA}=\mathrm{FFOA}+\mathrm{BBOA})$ was found to dominate the $\mathrm{OA}$ mass $(66.3 \%=43.9 \%+22.4 \%)$. Chloride $\left(\mathrm{Cl}^{-}\right)$had a great correlation with BC ( $r^{2}$ of 0.94$)$, suggesting it was mainly associated with primary emissions, for example, gasoline, diesel and coal combustion during wintertime in urban Beijing. Sulfate and nitrate are typically secondarily formed; therefore their correlations with BC were relatively weak $\left(r^{2}\right.$ of 0.64 for $\mathrm{SO}_{4}^{2-}$ vs. $\mathrm{BC}$ and 0.60 for $\mathrm{NO}_{3}^{-}$vs. $\mathrm{BC}$ ). Their properties are discussed in detail in the following sections.

\subsection{Chemically resolved size distributions of BC-containing particles}

Figure 3a shows the campaign-averaged mass-based size distributions of major $\mathrm{BC}$-coating species, including organics (BC-org), sulfate (BC-sulfate), nitrate (BC-nitrate), chloride (BC-Chl) and $\mathrm{BC}$ core itself. It should be noticed that the size distribution of $\mathrm{BC}$ was scaled from that of $m / z 24\left(\mathrm{C}_{2}^{+}\right)$, as other major carbon cluster ions might be significantly affected by other ions; for example, $\mathrm{C}_{1}^{+}$at $m / z, 12$ can be influenced by fragments from non-BC organics, $\mathrm{C}_{3}^{+}$at $m / z 36$ by $\mathrm{HCl}^{+}, \mathrm{C}_{4}^{+}$at $m / z 48$ by $\mathrm{SO}^{+}$and $\mathrm{C}_{5}^{+}$at $m / z 60$ by $\mathrm{C}_{2} \mathrm{H}_{4} \mathrm{O}_{2}^{+}$, etc. Similarly, the size distribution of $\mathrm{BC}-\mathrm{Chl}$ was scaled from $\mathrm{Cl}^{+}$signal at $m / z$ 35. As shown in Fig. 3a, on average, size distributions of $\mathrm{BC}$-sulfate, $\mathrm{BC}$-nitrate and $\mathrm{BC}$-org displayed similar patterns with a major peak at $\sim 550 \mathrm{~nm}$ (vacuum aerodynamic diameter, $D_{\text {va }}$ ), suggesting that they were relatively well mixed internally. However, the $\mathrm{BC}$ presented a remarkably different pattern with a much broader distribution and smaller peak sizes than its coating species, and in particular, relatively small particles tended to have thin coatings.

Figure $3 \mathrm{~b}-\mathrm{f}$ further present image plots of size distributions of the major aerosol components as a function of $R_{\mathrm{BC}}$ (a surrogate of coating thickness). In contrast to the average data shown in Fig. 3a, the coating species can be roughly classified into two modes separated by $R_{\mathrm{BC}}$ of $\sim 4.5$. Most sulfate and nitrate concentrated at $R_{\mathrm{BC}}>4.5$ (Fig. $3 \mathrm{~b}$ and c): sulfate peaked in a narrow $R_{\mathrm{BC}}$ range of 5.5-6.5, while significant nitrate mass could distribute across a wider $R_{\mathrm{BC}}$ range (even to $R_{\mathrm{BC}}$ of $\sim 8.0$ ). Only organics and chloride had a significant portion of mass distributed on relatively thinly coated $\mathrm{BC}$-containing particles at $R_{\mathrm{BC}}<4.5$ (Fig. 3e and f). Specifically, they both showed a submode locating in the regime with $R_{\mathrm{BC}}$ of $\sim 3.5-4.5$ and $D_{\text {va }}$ of $\sim 200$ $700 \mathrm{~nm}$. These submodes suggest that organics or chloride are partially from primary sources as freshly emitted BC are more likely thinly coated. This is consistent with organics including species from fossil fuel and biomass-burning combustion, revealed by the PMF analysis. Similarly, coal burning might contribute to chloride during wintertime in Beijing (Sun et al., 2016). As for sulfate and nitrate, since they are predominantly secondary species, they would coat BC cores due to chemical aging and are therefore mostly distributed at higher $R_{\mathrm{BC}}$.

\subsection{Sources of organic-coating species}

The high-resolution mass spectra of different factors of the organic coating, resolved from PMF analyses, their relative contributions and diurnal cycles of temporal variations relative to BC, are shown in Fig. 4. Figure 4a illustrates the mass profile of the fossil fuel combustion $\mathrm{OA}$ with $\mathrm{BC}$ carbon clusters $(\mathrm{FFOA}+\mathrm{BC})$. This factor had a low $\mathrm{O} / \mathrm{C}$ ratio of 0.16 . In this work, this factor might include emissions from 
(a)

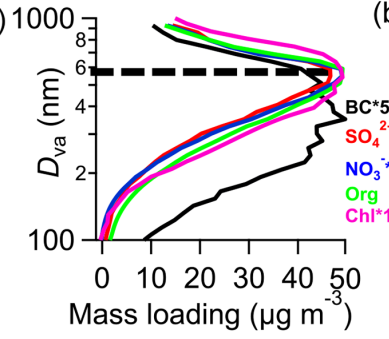

(d)

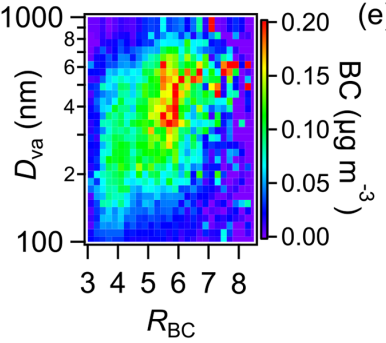

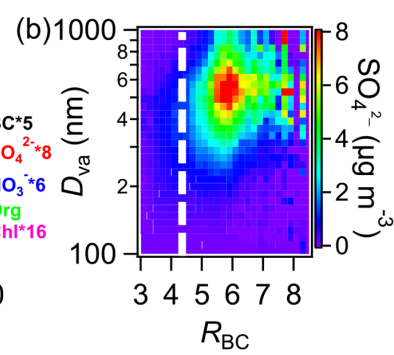

(e) 1000

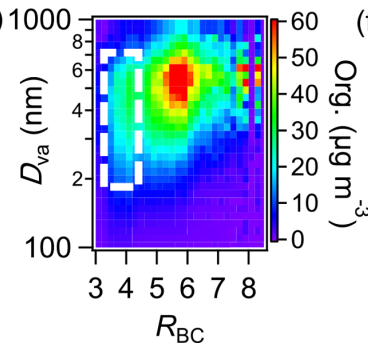

(c)

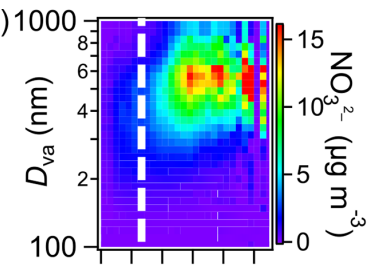

345678

$R_{\mathrm{BC}}$

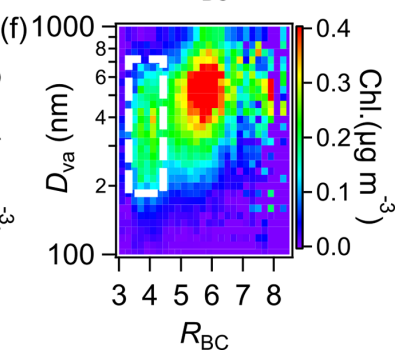

Figure 3. Mass-based campaign-averaged size distributions: (a) major coating components and BC cores, and (b-f) image plots of size distributions of sulfate, nitrate, $\mathrm{BC}$, organics and chloride as a function of $R_{\mathrm{BC}}$ (mass ratio of coating to $\mathrm{BC}$ ). (Note that size distributions of BC and chloride were scaled from those of $m / z 24$ and $m / z, 35$, respectively.)
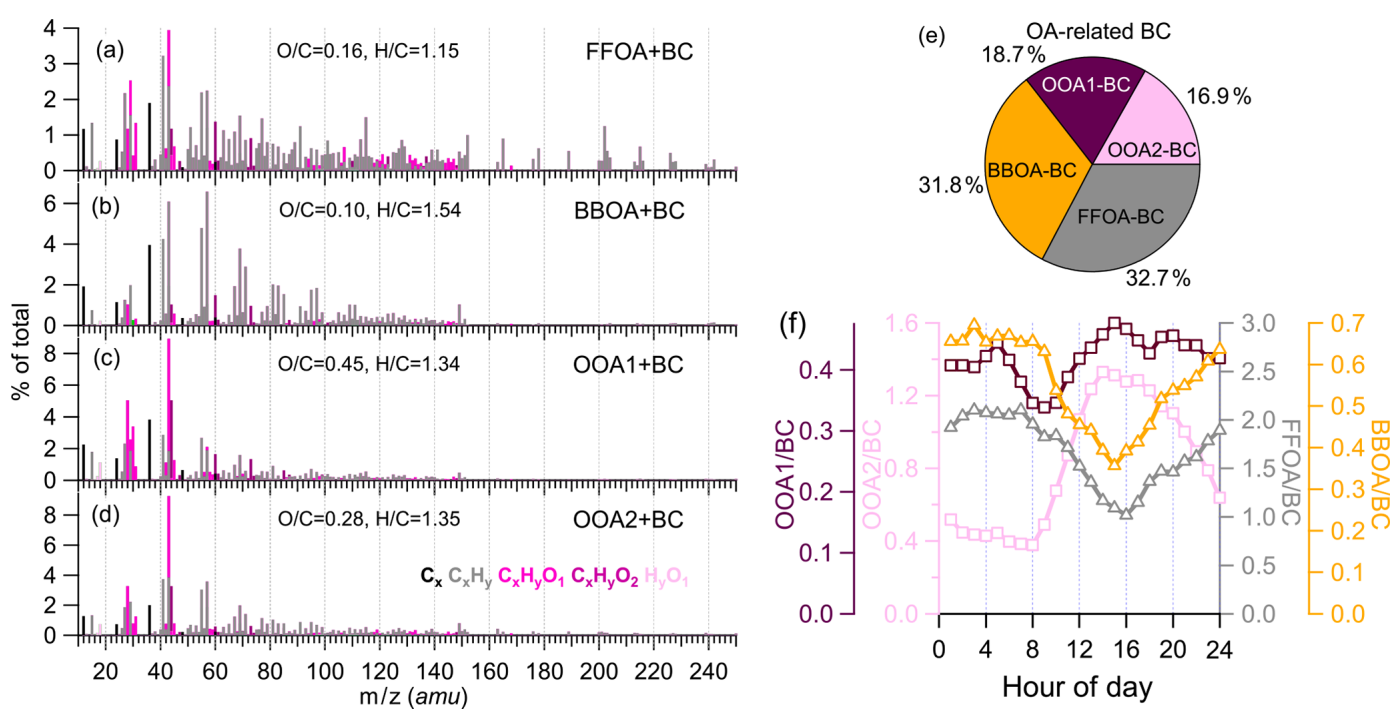

Figure 4. High-resolution mass spectra of (a) fossil fuel combustion OA (FFOA + BC), (b) biomass-burning OA (BBOA + BC), (c) $\mathrm{OOA} 1+\mathrm{BC},(\mathbf{d}) \mathrm{OOA} 2+\mathrm{BC}$, (e) mass fractions of the $\mathrm{BC}$ fragments apportioned in different OA factors, and (f) diurnal cycles of the four $\mathrm{OA}$ factors relative to $\mathrm{BC}$.

both traffic and coal combustion, as it contained a series of significant PAH ion fragments in the mass spectrum (PAH fragments are negligible in other factors), indicative of coal burning (Sun et al., 2014, 2016), and presented a good correlation with $\mathrm{C}_{4} \mathrm{H}_{9}^{+}\left(r^{2}\right.$ of 0.72$)$ - an AMS tracer ion of vehicle emissions (Zhang et al., 2005). Temporal variations in FFOA also correlated well with $\mathrm{C}_{9} \mathrm{H}_{7}^{+}\left(m / z 115, r^{2}\right.$ of 0.92$)$ and $\mathrm{Cl}^{-}\left(r^{2}\right.$ of 0.60$)$, which have been proposed as possible coal combustion tracer species (Yan et al., 2018; Sun et al., 2014). The FFOA / BC (Fig. 4f) appeared to be higher at nighttime than during the daytime. Note that the diurnal pattern of $\mathrm{BC}$ itself (Fig. 5c) was similar to that of FFOA / BC. The diurnal variations in $\mathrm{BC}$ might be influenced by both fossil fuel combustion activities and relatively low PBLH at nighttime. The fossil fuel combustion included coal burning and vehicle emissions (gasoline cars and the heavy-duty diesel vehicles that are only allowed to enter the city late at night). The mass ratios of different factors to $\mathrm{BC}$ have a smaller influence from PBLH; therefore high levels of FFOA / BC strongly indicate that co-emitted organic species with $\mathrm{BC}$ from fossil fuel combustion were enhanced at nighttime. 

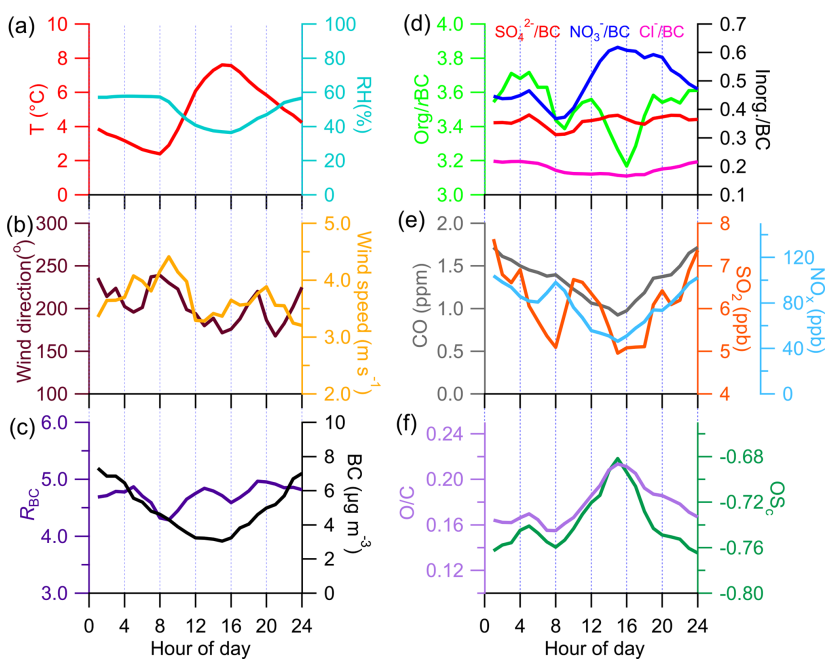

Figure 5. Diurnal cycles of (a) $T$ and $\mathrm{RH}$, (b) wind direction and wind speed, $(\mathbf{c})$ mass ratio of coatings to $\mathrm{BC}\left(R_{\mathrm{BC}}\right)$ and $\mathrm{BC}$, (d) org / $\mathrm{BC}, \mathrm{SO}_{4}^{2-} / \mathrm{BC}, \mathrm{NO}_{3}^{-} / \mathrm{BC}$ and $\mathrm{Cl}^{-} / \mathrm{BC}$, (e) mass loadings of gaseous species $\left(\mathrm{CO}, \mathrm{SO}_{2}, \mathrm{NO}_{x}\right)$ and (f) $\mathrm{O} / \mathrm{C}$ and oxidation state $\left(\mathrm{OS}_{\mathrm{c}}=2 \times \mathrm{O} / \mathrm{C}-\mathrm{H} / \mathrm{C}\right)$.

Figure $4 \mathrm{~b}$ shows the mass spectrum of BBOA and related $\mathrm{BC}$ clusters. One feature of this factor is that it had relatively high fractional contributions of $\mathrm{C}_{2} \mathrm{H}_{4} \mathrm{O}_{2}^{+}(1.47 \%$ of total) and $\mathrm{C}_{3} \mathrm{H}_{5} \mathrm{O}_{2}^{+}(0.95 \%)$, which are often regarded as AMS marker ions from levoglucosan emitted from biomassburning (Cubison et al., 2011; Mohr et al., 2009). Note that the FFOA also contained appreciable $\mathrm{C}_{2} \mathrm{H}_{4} \mathrm{O}_{2}^{+}$and $\mathrm{C}_{3} \mathrm{H}_{5} \mathrm{O}_{2}^{+}$ signals, partially because coal burning (such as lignite) can emit some levoglucosan as well (Yan et al., 2018). Nevertheless, the mass fractions of $\mathrm{C}_{2} \mathrm{H}_{4} \mathrm{O}_{2}^{+}$and $\mathrm{C}_{3} \mathrm{H}_{5} \mathrm{O}_{2}^{+}$in FFOA were smaller than those in BBOA, and they correlated much better with BBOA than those with FFOA (for example, $r^{2}$ of 0.90 for BBOA vs. $\mathrm{C}_{2} \mathrm{H}_{4} \mathrm{O}_{2}^{+}$, and 0.72 for FFOA vs. $\mathrm{C}_{2} \mathrm{H}_{4} \mathrm{O}_{2}^{+}$). The BBOA correlated very well with another biomass-burning tracer $-\mathrm{K}^{+}\left(r^{2}\right.$ of 0.90$)$. In addition, BBOA had negligible PAH ion fragments, while the FFOA contained remarkably high PAH signals. Such characteristics are generally in agreement with previous AMS findings at the same location during wintertime in Beijing (Sun et al., 2016). For these reasons, the second factor was identified as BBOA. The diurnal pattern of BBOA / BC reached minimum during afternoon and was high overall at nighttime, similarly to FFOA / BC, indicating the nighttime enhancement of BBrelated organics emissions in wintertime Beijing.

Besides the two POA factors, we also identified two secondary OA factors (OOA1 and OOA2), the $\mathrm{O} / \mathrm{C}$ ratios of which were 0.45 and 0.28 . OOA1 was the most oxidized $\mathrm{OA}$ factor that had a higher $\mathrm{CO}_{2}^{+} / \mathrm{C}_{2} \mathrm{H}_{3} \mathrm{O}^{+}$ratio than that of OOA2. The correlation between OOA1 and sulfate was better than with nitrate ( $r^{2}$ of 0.99 vs. 0.86 ). As a comparison, the less oxygenated OOA 2 correlated better with nitrate than with sulfate ( $r^{2}$ of 0.59 vs. 0.34 ). These characteristics are consistent with previous AMS-PMF results (Zhang et al., 2011). In contrast to the diurnal cycles of FFOA / BC and $\mathrm{BBOA} / \mathrm{BC}$, the OOA2 / $\mathrm{BC}$ ratio rose significantly from early morning and peaked in the afternoon $(\sim 15: 00)$. The diurnal pattern of OOA 1 / BC presented a similar peak at $\sim$ 15:00. This result demonstrates clear evidence of the important role of afternoon photochemical reactions to the formation of secondary organic species. However, the precursors leading to the formations of OOA 1 and OOA2 remain to be elucidated. Interestingly, for OOA1 / BC, in addition to the peak during the afternoon, it increased during early evening and remained at high levels until early morning. This result indicates that nighttime aqueous-phase processing (high levels of RH at nighttime shown in Fig. 5a) can also contribute to OOA1 production. As such behavior was not observed for OOA2 / BC, it agrees with previous field and laboratory findings that aqueous-phase reactions tend to produce more highly oxygenated species (Ervens et al., 2011; Ge et al., 2012; Herrmann et al., 2015; Xu et al., 2017).

Overall, the mass fractions of BC cores that were associated with fossil fuel combustion, biomass burning, less and more oxygenated secondary processes were $32.7 \%, 31.8 \%$, $18.7 \%$ and $16.9 \%$ (Fig. 4e). The organic coating of BC was predominantly primary species.

\subsection{Diurnal patterns of $\mathrm{BC}$ and coating species}

Figure 5 presents the diurnal cycles of meteorological parameters ( $T, \mathrm{RH}, \mathrm{WS}$ and $\mathrm{WD}), \mathrm{BC}$ concentrations and $R_{\mathrm{BC}}$, mass ratios of major species to $\mathrm{BC}$, gaseous species $\left(\mathrm{CO}, \mathrm{SO}_{2}\right.$ and $\left.\mathrm{NO}_{x}\right), \mathrm{O} / \mathrm{C}$ and $\mathrm{OS}_{\mathrm{c}}$ (oxidation state, defined as $2 \times \mathrm{O} / \mathrm{C}-\mathrm{H} / \mathrm{C}$ ) (Kroll et al., 2011). Note that $\mathrm{BC}$ did not present a peak at 08:00, yet $R_{\mathrm{BC}}$, org/BC, $\mathrm{SO}_{4}^{2-} / \mathrm{BC}$, $\mathrm{NO}_{3}^{-} / \mathrm{BC}$ and $\mathrm{Cl}^{-} / \mathrm{BC}$ were all low at $\sim 08: 00$. This was likely attributed to an increase in the mass fractions of fresh and barely coated BC-containing particles (rather than the increase in absolute concentrations of fresh BC-containing particles) emitted during morning rush hours from traffic emissions, etc. This was consistent with the decreases in $\mathrm{O} / \mathrm{C}$ and $\mathrm{OS}_{\mathrm{c}}$ and increases in $\mathrm{CO}$ and $\mathrm{NO}_{2}$ at 08:00 on the day. On the contrary, the $R_{\mathrm{BC}}$ drop at $\sim 16: 00$ was unlikely due to the influence of the afternoon rush hour, as there were no increases in $\mathrm{CO}, \mathrm{NO}_{2}$, and both $\mathrm{O} / \mathrm{C}$ and $\mathrm{OS}_{\mathrm{c}}$ were at high levels. In fact, the $16: 00 R_{\mathrm{BC}}$ drop was mainly caused by the large decrease in org / $\mathrm{BC}$ (as $\mathrm{SO}_{4}^{2-} / \mathrm{BC}, \mathrm{NO}_{3}^{-} / \mathrm{BC}^{-}$and $\mathrm{Cl}^{-} / \mathrm{BC}$ did not decrease at 16:00, Fig. $5 \mathrm{~d}$ ), which were mainly the portions of fossil fuel and biomass-burning OA (Fig. 4f).

The diurnal variation in $\mathrm{NO}_{3}^{-} / \mathrm{BC}$ peaked at $\sim 15: 00-$ 16:00, consistent with the variation in $T$ and similar to those in the previous reports during wintertime in Beijing (Ge et al., 2017a; Sun et al., 2016), reflecting the dominant contribution of photochemical formation of nitrate. $\mathrm{SO}_{4}^{2-} / \mathrm{BC}$ showed a relatively small afternoon increase, indicating partial sulfate was produced from photochemical activities; it also presented a nighttime enhancement, 
(a)

Clean period $\left(2.62 \mu \mathrm{g} \mathrm{m}^{-3}\right)$

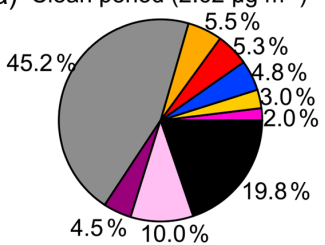

(b) Pollution period $\left(38.37 \mathrm{\mu g} \mathrm{m}^{-3}\right.$

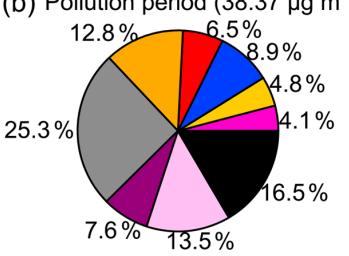

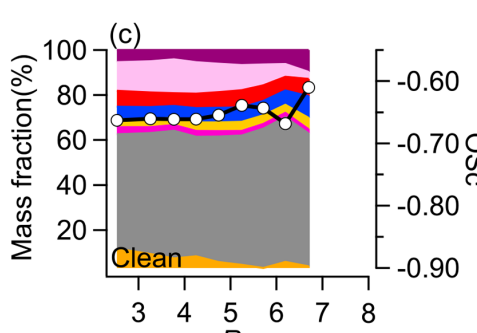

(d) $\quad R_{\mathrm{BC}}$

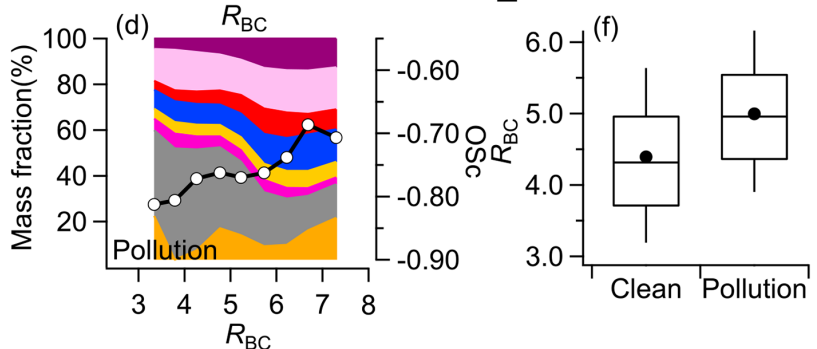

Figure 6. (a, b) Average compositions of BC-containing particles during clean and polluted periods, $(\mathbf{c}, \mathbf{d})$ mass fractions of the non-BC coating components (left $y$ axis) and $\mathrm{OS}_{\mathrm{c}}$ (right $y$ axis) during clean and polluted periods as a function of $R_{\mathrm{BC}}$, box plots of $\mathrm{BC}$ mass loadings (e) and $R_{\mathrm{BC}}$ (f) during clean and polluted periods (colors of the components are consistent with those in Fig. 2).

similar to OOA1 / BC, suggesting the sulfate formation in aqueous-phase, consistent with the nighttime increase in $\mathrm{RH}$ and decrease in temperature (Fig. 5a). Due to increases in FFOA / BC, BBOA / BC and OOA1 / BC (the portion likely from aqueous-phase production), org / $\mathrm{BC}$ remained at high levels at nighttime. All these increases were added together, leading to high $R_{\mathrm{BC}}$ at nighttime. In addition, $\mathrm{Cl}^{-} / \mathrm{BC}$ varied generally similar to those of FFOA / BC and BBOA / BC, again indicating its strong association with primary emissions.

\subsection{Characteristics of coating species during different periods}

\subsubsection{Coating compositions during clean and polluted periods}

Figure 6 shows the variation in BC-coating composition as a function of $R_{\mathrm{BC}}$ during clean periods (CPs) and polluted periods (PPs) (divided by the concentration of $10 \mu \mathrm{g} \mathrm{m}^{-3}$ ). Contrasting differences in the coating composition during these two cases was observed: primary OA (especially FFOA) appeared to be the most abundant component during CPs, while mass contributions of secondary organic and inorganic species were remarkably high during PPs (Fig. 6a and b), and the average $R_{\mathrm{BC}}$ during PPs $(\sim 5.1)$ was also higher than that during CPs $(\sim 4.5)$ (Fig. 6f). These results again reinforce the importance of secondarily formed species to the heavy haze pollution in urban Beijing (Huang et al., 2014). Furthermore, the BC-coating composition and $\mathrm{OS}_{\mathrm{c}}$ were both relatively stable compared to $R_{\mathrm{BC}}$ during CPs (Fig. 6c). On the contrary, during PPs, with the increase in $R_{\mathrm{BC}}$, the mass fractions of secondary species (OOA1, nitrate and sulfate) clearly increased, especially at $R_{\mathrm{BC}}>5$; consistently, $\mathrm{OS}_{\mathrm{c}}$ of organic coating increased from $\sim-0.85$ to $>-0.70$. Such behavior again highlights the contribution of the chemical aging process to the heavy haze pollution.

Relative to other observations (J. Wang et al., 2017; Massoli et al., 2015; Cappa et al., 2012), the levels of $R_{\mathrm{BC}}$ during both CPs and PPs are much smaller than those for highly aged $\mathrm{BC}$, which might have $R_{\mathrm{BC}}>10$. As BC-containing particles in urban Beijing were influenced by multiple local and regional primary sources, the relative amount of secondarily formed coating species would be less than those of highly aged $\mathrm{BC}$; therefore this lower $R_{\mathrm{BC}}$ is expected. On the other hand, the $R_{\mathrm{BC}}$ levels are generally higher than those found for the BC-containing particles in Los Angeles where the average $R_{\mathrm{BC}}$ was typically smaller than 4 due to the direct and prominent influence of vehicle emissions (Lee et al., 2017). Regarding the variations in coating composition in relation to $R_{\mathrm{BC}}$, the behavior during PPs is in fact consistent with a few previous field measurement results in American and European urban locations (Massoli et al., 2015; Liu et al., 2017; Lee et al., 2017; Cappa et al., 2012; Collier et al., 2018), indicating a general trend for more aged $\mathrm{BC}$-containing particles in urban areas to have a thicker coating. Yet this property can be altered if significant POA emissions exist, such as in the case during CPs in this work, and a case with heavy BBOA influences observed in the Tibeten Plateau (J. Wang et al., 2017).

\subsubsection{Coating compositions during two polluted episodes}

Although we demonstrated in Sect. 3.5.1 that the heavy pollution of BC-containing particles was on average associated with more secondary species, the underlying governing fac- 

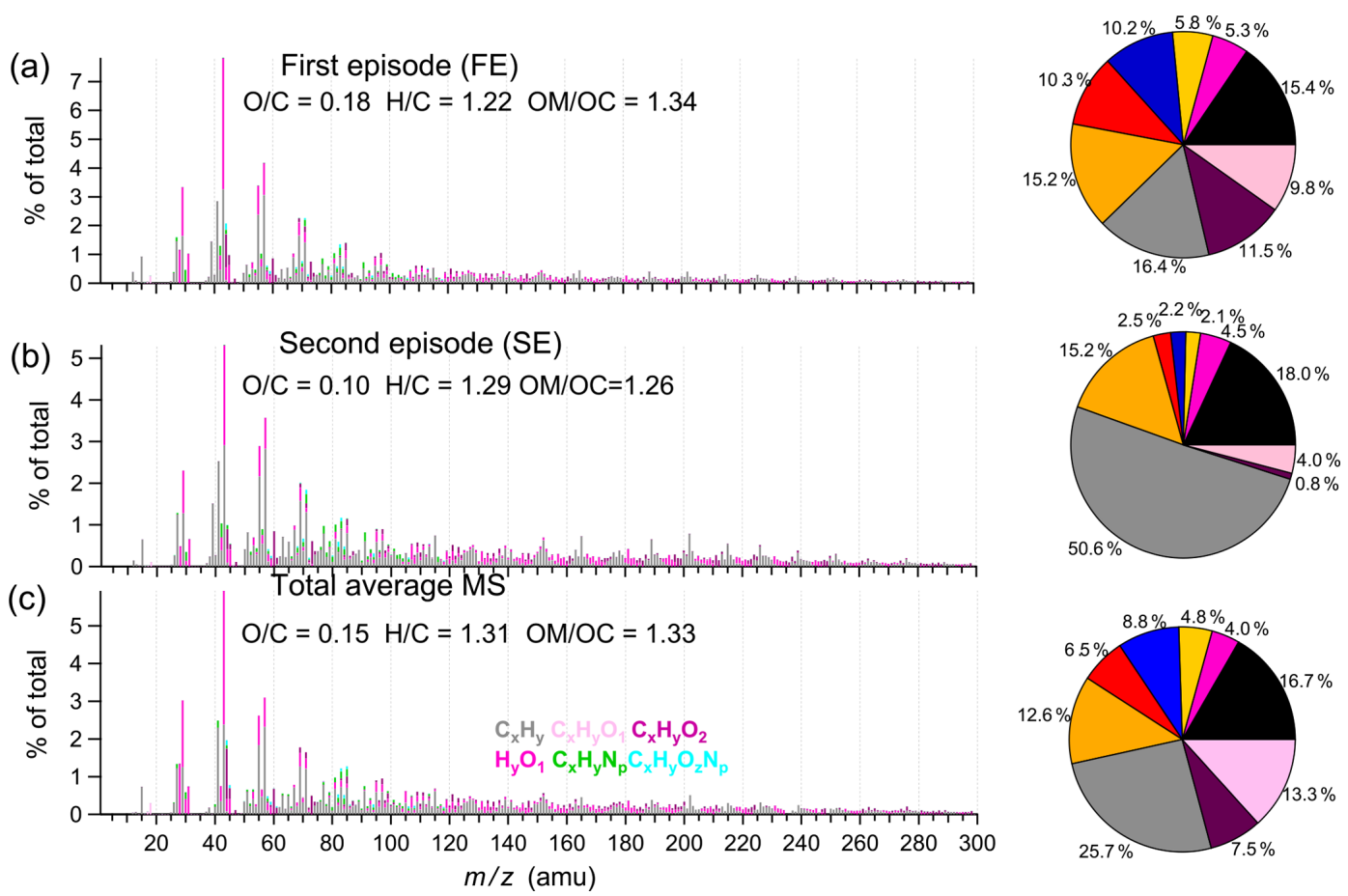

Figure 7. High-resolution mass spectra of the average OA at different episodes: (a) first episode (FE), (b) second episode (SE) and (c) whole campaign (inset pies show the average compositions during corresponding episodes; colors of different components are consistent with those in Fig. 2).

tors of individual pollution events might vary. Here we investigated the characteristics of BC-containing particles in two most polluted episodes occurring during the campaign. The first episode (FE) was accompanied with relatively high RH (from 18:00 of 3 December to 08:00 of 4 December 2016), while the second episode (SE) was dominated by primary emissions (from 00:00 to 06:00 of 11 December 2016). The average mass loadings of $\mathrm{BC}$ cores and $\mathrm{BC}$-containing particles were 18.1 and $123.1 \mu \mathrm{g} \mathrm{m}^{-3}$ during $\mathrm{FE}$ and 14.4 and $80.0 \mu \mathrm{g} \mathrm{m}^{-3}$ during SE, respectively - both were much higher than the campaign-averaged $\mathrm{BC}$ of $4.9 \mu \mathrm{g} \mathrm{m}^{-3}$ and BC-containing particles of $29.4 \mu \mathrm{g} \mathrm{m}^{-3}$. Back trajectories, wind rose plots and distributions of the wind speeds and directions of these two episodes were provided in Fig. S5, showing that these two episodes had remarkably different air mass origins and sources.

For FE, the average $T$ and $\mathrm{RH}$ were $\sim 4.2^{\circ} \mathrm{C}$ and $\sim 78 \%$. The average $T$ was close to the campaign-averaged value of $4.8^{\circ} \mathrm{C}$, but the air was more humid than the campaignaveraged $\mathrm{RH}$ of $\sim 50 \%$. Correspondingly, we observed remarkable elevations of the mass contributions of sulfate from $6.5 \%$ to $10.3 \%$, nitrate from $8.8 \%$ to $10.2 \%$ and OOA1 from $7.5 \%$ to $11.5 \%$ (Fig. $7 \mathrm{a}$ and c). Such enhancements were very likely linked with aqueous-phase processing as this episode occurred at nighttime and was characterized with high RH conditions. During FE, nitrate and sulfate also correlated very well $\left(r^{2}\right.$ of 0.94 ; Fig. S6); therefore the formation of nitrate would also be related to aqueousphase processing in this episode. Consistently, nitrate and sulfate formations driven by high RH in the North China Plain have been proven previously (Kuang et al., 2016; Sun et al., 2018; Wu et al., 2018). As a comparison, the mass fraction of photochemical-relevant OOA2 decreased significantly from campaign-averaged $13.3 \%$ to $9.8 \%$. In addition, the mass fraction of $\mathrm{Cl}^{-}$also increased from campaignaveraged $4.0 \%$ to $5.3 \%$; meanwhile, we found that relative to the campaign-averaged values, the $\mathrm{KCl}^{+} / \mathrm{BC}$ ratio decreased $14 \%$, the $\mathrm{K}_{3} \mathrm{SO}_{4}^{+} / \mathrm{BC}$ ratio increased $28 \%$, possibly indicating that the heterogeneous replacement reactions of coal-burning-related $\mathrm{Cl}^{-}$by $\mathrm{SO}_{4}^{2-}$ during FE (Fig. S6). Overall, mainly due to the aqueous-phase production of secondary coating components, compared to campaign-averaged values, the average $R_{\mathrm{BC}}$ became larger during FE (5.5 vs. 5.0), $\mathrm{OA}$ became more oxygenated $(\mathrm{O} / \mathrm{C}$ of 0.18 vs. 0.15$)$, and size distributions of OA, sulfate and nitrate all shifted to larger peak sizes (Fig. S7a).

On the other hand, for SE, even though it also occurred at nighttime, the average RH was significantly low $(\sim 47 \%)$, and it was overwhelmingly dominated by primary species (50.6\% of FFOA, $15.2 \%$ of BBOA and $18 \%$ of BC). Secondary sulfate and nitrate only took up $2.5 \%$ and $2.2 \%$ of the total mass of BC-containing particles. Nighttime aqueousphase-related OOA 1 contribution was nearly negligible (only $0.8 \%$ ), which, in another way, manifests that at nighttime 
OOA1 production was strongly associated with high RH conditions. Due to the contribution of fresh primary emissions, the coating of OA was less oxygenated than that of campaign-averaged $\mathrm{OA}(\mathrm{O} / \mathrm{C}$ of 0.12 vs. 0.15$)$, and the average $R_{\mathrm{BC}}$ during SE was consistently smaller (4.5 vs. 5.0). Mass spectrum of BC-org (Fig. 7b) also contained significant PAH fragments, in line with the large contribution from FFOA (mainly coal combustion). The average size distribution of OA during SE was broader and peaked in a smaller diameter $\left(<500 \mathrm{~nm} D_{\text {va }}\right)$ (Fig. S7b) in response to the dominance of POA. Occurrence of the highly polluted SE demonstrates that, even though the pollution of BC-containing particles in urban Beijing during winter are on average governed by secondary species, local primary emissions can sometimes lead to serious and short-term pollution events as well.

\section{Conclusions}

As part of the UK-China 2016 APHH winter campaign, for the first time, an Aerodyne SP-AMS was introduced to exclusively determine the chemical compositions of BCcontaining particles in urban Beijing. We found the average concentrations of $\mathrm{BC}$ and its coating species were 4.9 and $24.5 \mu \mathrm{g} \mathrm{m}^{-3}$; therefore the $R_{\mathrm{BC}}$ (mass ratio of coating to $\mathrm{BC})$ was $\sim 5.0$. The coating was dominated by organics (59.4\% of total mass of BC-containing particles), followed by nitrate and sulfate (15.3\% in total). Size distribution data demonstrate that larger $\mathrm{BC}$-containing particles tend to have a thicker coating, more secondary species and more internally mixed coating components. PMF analyses of organic coating further identified two POA factors relevant to fossil fuel and biomass burning, which dominated the total OA mass. Two SOA factors were also separated, and both of them were found to be mainly contributed to by photochemical activities; besides a fraction of the highly oxidized OA factor could be produced by nighttime aqueous-phase reactions. In addition, significant photochemical formation of nitrate rather than sulfate was observed in the afternoon.

Comparisons of the coating compositions between clean and polluted periods shows the critically important role of chemical aging for the pollution of BC-containing particles in urban Beijing. We also found that, in one case, aqueousphase production might lead to serious pollution under high RH conditions, while in another case, fossil fuel combustion could cause extreme and short-term heavy pollution. Comparisons between the BC-containing particles and the total submicron aerosol particles during this campaign will be presented in detail in the near future.

Data availability. The data in this study are available from the authors upon request (caxinra@163.com).
Supplement. The supplement related to this article is available online at: https://doi.org/10.5194/acp-19-447-2019-supplement.

Author contributions. JW, XG and YS designed the research. JF, YW, XG, FS, JZ and CX conducted the measurements. JW, DL, XG, CX, QW and WX analyzed the data. JW, DL and XG wrote the paper. JH, JA, PF and HC reviewed and commented on the paper.

Competing interests. The authors declare that they have no conflict of interest.

Special issue statement. This article is part of the special issue "In-depth study of air pollution sources and processes within Beijing and its surrounding region (APHH-Beijing) (ACP/AMT interjournal SI)". It is not associated with a conference.

Acknowledgements. This work was supported by the National Key R\&D programme of China (2016YFC0203501), the Natural Science Foundation of China (21777073, 91544220, 21577065 and 41571130034), the International ST Cooperation Program of China (2014DFA90780), and the UK Natural Environment Research Council (grant reference NE/N00695X/1).

Edited by: Yongjie Li

Reviewed by: two anonymous referees

\section{References}

Aiken, A. C., Decarlo, P. F., Kroll, J. H., Worsnop, D. R., Huffman, J. A., Docherty, K. S., Ulbrich, I. M., Mohr, C., Kimmel, J. R., Sueper, D., Sun, Y., Zhang, Q., Trimborn, A., Northway, M., Ziemann, P. J., Canagaratna, M. R., Onasch, T. B., Alfarra, M. R., Prevot, A. S. H., Dommen, J., Duplissy, J., Metzger, A., Baltensperger, U., and Jimenez, J. L.: O/C and OM/OC ratios of primary, secondary, and ambient organic aerosols with high-resolution time-of-flight aerosol mass spectrometry, Environ. Sci. Tech., 42, 4478-4485, 2008.

Bond, T. C., Doherty, S. J., Fahey, D. W., Forster, P. M., Berntsen, T., DeAngelo, B. J., Flanner, M. G., Ghan, S., Kärcher, B., Koch, D., Kinne, S., Kondo, Y., Quinn, P. K., Sarofim, M. C., Schultz, M. G., Schulz, M., Venkataraman, C., Zhang, H., Zhang, S., Bellouin, N., Guttikunda, S. K., Hopke, P. K., Jacobson, M. Z., Kaiser, J. W., Klimont, Z., Lohmann, U., Schwarz, J. P., Shindell, D., Storelvmo, T., Warren, S. G., and Zender, C. S.: Bounding the role of black carbon in the climate system: A scientific assessment, J. Geophy. Res.-Atmos., 118, 5380-5552, 2013.

Canagaratna, M. R., Jayne, J. T., Jimenez, J. L., Allan, J. D., Alfarra, M. R., Zhang, Q., Onasch, T. B., Drewnick, F., Coe, H., Middlebrook, A., Delia, A., Williams, L. R., Trimborn, A. M., Northway, M. J., DeCarlo, P. F., Kolb, C. E., Davidovits, P., and Worsnop, D. R.: Chemical and microphysical characterization of ambient aerosols with the aerodyne aerosol mass spectrometer, Mass Spectrom. Rev., 26, 185-222, 2007. 
Canagaratna, M. R., Massoli, P., Browne, E. C., Franklin, J. P., Wilson, K. R., Onasch, T. B., Kirchstetter, T. W., Fortner, E. C., Kolb, C. E., Jayne, J. T., Kroll, J. H., and Worsnop, D. R.: Chemical compositions of black carbon particle cores and coatings via soot particle aerosol mass spectrometry with photoionization and electron ionization, J. Phys. Chem. A, 119, 4589-4599, 2015.

Cappa, C. D., Onasch, T. B., Massoli, P., Worsnop, D. R., Bates, T. S., Cross, E. S., Davidovits, P., Hakala, J., Hayden, K. L., Jobson, B. T., Kolesar, K. R., Lack, D. A., Lerner, B. M., Li, S.-M., Mellon, D., Nuaaman, I., Olfert, J. S., Petäjä, T., Quinn, P. K., Song, C., Subramanian, R., Williams, E. J., and Zaveri, R. A.: Radiative absorption enhancements due to the mixing state of atmospheric black carbon, Science, 337, 1078-1081, 2012.

Chen, C., Fan, X., Shaltout, T., Qiu, C., Ma, Y., Goldman, A., and Khalizov, A. F.: An unexpected restructuring of combustion soot aggregates by subnanometer coatings of polycyclic aromatic hydrocarbons, Geophys. Res. Lett., 43, 11080-11088, 2016.

Chen, Y., Schleicher, N., Fricker, M., Cen, K., Liu, X.-L., Kaminski, U., Yu, Y., Wu, X., and Norra, S.: Long-term variation of black carbon and PM2.5 in Beijing, China with respect to meteorological conditions and governmental measures, Environ. Pollut., 212, 269-278, 2016.

Cheng, Y., He, K.-B., Engling, G., Weber, R., Liu, J., Du, Z.-Y., and Dong, S.-P.: Brown and black carbon in Beijing aerosol: Implications for the effects of brown coating on light absorption by black carbon, Sci. Total. Environ., 599-600, 1047-1055, 2017.

Collier, S., Williams, L. R., Onasch, T. B., Cappa, C. D., Zhang, X., Russell, L. M., Chen, C.-L., Sanchez, K. J., Worsnop, D. R., and Zhang, Q.: Influence of emissions and aqueous processing on particles containing black carbon in a polluted urban environment: insights from a soot particle-aerosol mass spectrometer, J. Geophys. Res.-Atmos., 123, 6648-6666, 2018.

Cubison, M. J., Ortega, A. M., Hayes, P. L., Farmer, D. K., Day, D., Lechner, M. J., Brune, W. H., Apel, E., Diskin, G. S., Fisher, J. A., Fuelberg, H. E., Hecobian, A., Knapp, D. J., Mikoviny, T., Riemer, D., Sachse, G. W., Sessions, W., Weber, R. J., Weinheimer, A. J., Wisthaler, A., and Jimenez, J. L.: Effects of aging on organic aerosol from open biomass burning smoke in aircraft and laboratory studies, Atmos. Chem. Phys., 11, 12049-12064, https://doi.org/10.5194/acp-11-12049-2011, 2011.

Cui, X., Wang, X., Yang, L., Chen, B., Chen, J., Andersson, A., and Gustafsson, Ö.: Radiative absorption enhancement from coatings on black carbon aerosols, Sci. Total Environ., 551-552, 51-56, 2016.

Ding, A. J., Huang, X., Nie, W., Sun, J. N., Kerminen, V. M., Petäjä, T., Su, H., Cheng, Y. F., Yang, X. Q., Wang, M. H., Chi, X. G., Wang, J. P., Virkkula, A., Guo, W. D., Yuan, J., Wang, S. Y., Zhang, R. J., Wu, Y. F., Song, Y., Zhu, T., Zilitinkevich, S., Kulmala, M., and Fu, C. B.: Enhanced haze pollution by black carbon in megacities in China, Geophys. Res. Lett., 43, 2873-2879, 2016.

Dusek, U., Reischl, G. P., and Hitzenberger, R.: CCN activation of pure and coated carbon black particles, Environ. Sci. Tech., 40, 1223-1230, 2006.

Dusek, U., Frank, G. P., Curtius, J., Drewnick, F., Schneider, J., Kurten, A., Rose, D., Andreae, M. O., Borrmann, S., and Pöschl, U.: Enhanced organic mass fraction and decreased hygroscopicity of cloud condensation nuclei $(\mathrm{CCN})$ during new particle formation events, Geophys. Res. Lett., 37, 174-180, 2010.
Ervens, B., Turpin, B. J., and Weber, R. J.: Secondary organic aerosol formation in cloud droplets and aqueous particles (aqSOA): a review of laboratory, field and model studies, Atmos. Chem. Phys., 11, 11069-11102, https://doi.org/10.5194/acp-1111069-2011, 2011.

Ge, X., Zhang, Q., Sun, Y., Ruehl, C. R., and Setyan, A.: Effect of aqueous-phase processing on aerosol chemistry and size distributions in Fresno, California, during wintertime, Environ. Chem., 9, 221-235, 2012.

Ge, X., He, Y., Sun, Y., Xu, J., Wang, J., Shen, Y., and Chen, M.: Characteristics and formation mechanisms of fine particulate nitrate in typical urban areas in china, Atmosphere, 8, 62, https://doi.org/10.3390/atmos8030062, 2017a.

Ge, X., Li, L., Chen, Y., Chen, H., Wu, D., Wang, J., Xie, X., Ge, S., Ye, Z., Xu, J., and Chen, M.: Aerosol characteristics and sources in Yangzhou, China resolved by offline aerosol mass spectrometry and other techniques, Environ. Pollut., 225, 74-85, $2017 \mathrm{~b}$.

Herrmann, H., Schaefer, T., Tilgner, A., Styler, S. A., Weller, C., Teich, M., and Otto, T.: Tropospheric aqueous-phase chemistry: kinetics, mechanisms, and its coupling to a changing gas phase, Chem. Rev., 115, 4259, https://doi.org/10.1021/cr500447k, 2015.

Huang, R.-J., Zhang, Y., Bozzetti, C., Ho, K.-F., Cao, J.-J., Han, Y., Daellenbach, K. R., Slowik, J. G., Platt, S. M., Canonaco, F., Zotter, P., Wolf, R., Pieber, S. M., Bruns, E. A., Crippa, M., Ciarelli, G., Piazzalunga, A., Schwikowski, M., Abbaszade, G., SchnelleKreis, J., Zimmermann, R., An, Z., Szidat, S., Baltensperger, U., Haddad, I. E., and Prévôt, A. S. H.: High secondary aerosol contribution to particulate pollution during haze events in China, Nature, 514, 218-222, 2014.

Jacobson, M. Z.: Strong radiative heating due to the mixing state of black carbon in atmospheric aerosols, Nature, 409, 695-697, 2001.

Jayne, J. T., Leard, D. C., Zhang, X., Davidovits, P., Smith, K. A., Kolb, C. E., and Worsnop, D. R.: Development of an aerosol mass spectrometer for size and composition analysis of submicron particles, Aerosol Sci. Tech., 33, 49-70, 2000.

Ji, D., Li, L., Pang, B., Xue, P., Wang, L., Wu, Y., Zhang, H., and Wang, Y.: Characterization of black carbon in an urban-rural fringe area of Beijing, Environ. Pollut., 223, 524-534, 2017.

Kroll, J. H., Donahue, N. M., Jimenez, J. L., Kessler, S. H., Canagaratna, M. R., Wilson, K. R., Altieri, K. E., Mazzoleni, L. R., Wozniak, A. S., Bluhm, H., Mysak, E. R., Smith, J. D., Kolb, C. E., and Worsnop, D. R.: Carbon oxidation state as a metric for describing the chemistry of atmospheric organic aerosol, Nat. Chem., 3, 133-139, 2011.

Kuang, Y., Zhao, C. S., Ma, N., Liu, H. J., Bian, Y. X., Tao, J. C., and $\mathrm{Hu}, \mathrm{M}$. : Deliquescent phenomena of ambient aerosols on the North China Plain, Geophys. Res. Lett., 43, 8744-8750, 2016.

Laborde, M., Schnaiter, M., Linke, C., Saathoff, H., Naumann, K.H., Möhler, O., Berlenz, S., Wagner, U., Taylor, J. W., Liu, D., Flynn, M., Allan, J. D., Coe, H., Heimerl, K., Dahlkötter, F., Weinzierl, B., Wollny, A. G., Zanatta, M., Cozic, J., Laj, P., Hitzenberger, R., Schwarz, J. P., and Gysel, M.: Single Particle Soot Photometer intercomparison at the AIDA chamber, Atmos. Meas. Tech., 5, 3077-3097, https://doi.org/10.5194/amt-5-30772012, 2012.

Lee, A. K. Y., Willis, M. D., Healy, R. M., Onasch, T. B., and Abbatt, J. P. D.: Mixing state of carbonaceous aerosol 
in an urban environment: single particle characterization using the soot particle aerosol mass spectrometer (SP-AMS), Atmos. Chem. Phys., 15, 1823-1841, https://doi.org/10.5194/acp15-1823-2015, 2015.

Lee, A. K. Y., Chen, C.-L., Liu, J., Price, D. J., Betha, R., Russell, L. M., Zhang, X., and Cappa, C. D.: Formation of secondary organic aerosol coating on black carbon particles near vehicular emissions, Atmos. Chem. Phys., 17, 15055-15067, https://doi.org/10.5194/acp-17-15055-2017, 2017.

Li, W., Sun, J., Xu, L., Shi, Z., Riemer, N., Sun, Y., Fu, P., Zhang, J., Lin, Y., Wang, X., Shao, L., Chen, J., Zhang, X., Wang, Z., and Wang, W.: A conceptual framework for mixing structures in individual aerosol particles, J. Geophys. Res.-Atmos., 121, 1378413798, 2016.

Liu, D., Allan, J., Whitehead, J., Young, D., Flynn, M., Coe, H., McFiggans, G., Fleming, Z. L., and Bandy, B.: Ambient black carbon particle hygroscopic properties controlled by mixing state and composition, Atmos. Chem. Phys., 13, 2015-2029, https://doi.org/10.5194/acp-13-2015-2013, 2013.

Liu, D., Whitehead, J., Alfarra, M. R., Reyes-Villegas, E., Spracklen, D. V., Reddington, C. L., Kong, S., Williams, P. I., Ting, Y.-C., Haslett, S., Taylor, J. W., Flynn, M. J., Morgan, W. T., McFiggans, G., Coe, H., and Allan, J. D.: Black-carbon absorption enhancement in the atmosphere determined by particle mixing state, Nat. Geosci., 10, 184-188, 2017.

Liu, D., Joshi, R., Wang, J., Yu, C., Allan, J. D., Coe, H., Flynn, M. J., Xie, C., Lee, J., Squires, F., Kotthaus, S., Grimmond, S., Ge, X., Sun, Y., and Fu, P.: Contrasting physical properties of black carbon in urban Beijing between winter and summer, Atmos. Chem. Phys. Discuss., https://doi.org/10.5194/acp-2018-1142, in review, 2018.

Liu, Q., Ma, T., Olson, M. R., Liu, Y., Zhang, T., Wu, Y., and Schauer, J. J.: Temporal variations of black carbon during haze and non-haze days in Beijing, Sci. Rep., 6, 33331, https://doi.org/10.1038/srep33331, 2016.

Liu, S., Aiken, A. C., Gorkowski, K., Dubey, M. K., Cappa, C. D., Williams, L. R., Herndon, S. C., Massoli, P., Fortner, E. C., Chhabra, P. S., Brooks, W. A., Onasch, T. B., Jayne, J. T., Worsnop, D. R., China, S., Sharma, N., Mazzoleni, C., Xu, L., Ng, N. L., Liu, D., Allan, J. D., Lee, J. D., Fleming, Z. L., Mohr, C., Zotter, P., Szidat, S., and Prevot, A. S. H.: Enhanced light absorption by mixed source black and brown carbon particles in UK winter, Nat. Commun., 6, 8435, https://doi.org/10.1038/ncomms9435, 2015.

Massoli, P., Onasch, T. B., Cappa, C. D., Nuamaan, I., Hakala, J., Hayden, K., Li, S.-M., Sueper, D. T., Bates, T. S., Quinn, P. K., Jayne, J. T., and Worsnop, D. R.: Characterization of black carbon-containing particles from soot particle aerosol mass spectrometer measurements on the R/V Atlantis during CalNex 2010, J. Geophys. Res.-Atmos., 120, 2014JD022834, https://doi.org/10.1002/2014JD022834, 2015.

Meng, J., Liu, J., Guo, S., Li, J., Li, Z., and Tao, S.: Trend and driving forces of Beijing's black carbon emissions from sectoral perspectives, J. Clean. Prod., 112, 1272-1281, 2016.

Mohr, C., Huffman, J. A., Cubison, M. J., Aiken, A. C., Docherty, K. S., Kimmel, J. R., Ulbrich, I. M., Hannigan, M., and Jimenez, J. L.: Characterization of primary organic aerosol emissions from meat cooking, trash burning, and motor vehicles with highresolution aerosol mass spectrometry and comparison with am- bient and chamber observations, Environ. Sci. Tech., 43, 24432449, 2009.

Onasch, T. B., Trimborn, A., Fortner, E. C., Jayne, J. T., Kok, G. L., Williams, L. R., Davidovits, P., and Worsnop, D. R.: Soot particle aerosol mass spectrometer: development, validation, and initial application, Aerosol Sci. Tech., 46, 804-817, 2012.

Paatero, P. and Tapper, U.: Positive matrix factorization: A nonnegative factor model with optimal utilization of error estimates of data values, Environmetrics, 5, 111-126, 1994.

Peng, J., Hu, M., Guo, S., Du, Z., Zheng, J., Shang, D., Levy, Z. M., Zeng, L., Shao, M., and Wu, Y. S.: Markedly enhanced absorption and direct radiative forcing of black carbon under polluted urban environments, P. Natl. Acad. Sci. USA, 113, 4266, https://doi.org/10.1073/pnas.1602310113, 2016.

Pokhrel, R. P., Beamesderfer, E. R., Wagner, N. L., Langridge, J. M., Lack, D. A., Jayarathne, T., Stone, E. A., Stockwell, C. E., Yokelson, R. J., and Murphy, S. M.: Relative importance of black carbon, brown carbon, and absorption enhancement from clear coatings in biomass burning emissions, Atmos. Chem. Phys., 17, 5063-5078, https://doi.org/10.5194/acp-17-5063-2017, 2017.

Ramanathan, V. and Carmichael, G.: Global and regional climate changes due to black carbon, Nat. Geosci, 1, 221-227, 2008.

Schleicher, N., Cen, K., and Norra, S.: Daily variations of black carbon and element concentrations of atmospheric particles in the Beijing megacity - Part 1: general temporal course and source identification, Chem. Erde-Geochem., 73, 51-60, 2013a.

Schleicher, N., Norra, S., Fricker, M., Kaminski, U., Chen, Y., Chai, F., Wang, S., Yu, Y., and Cen, K.: Spatio-temporal variations of black carbon concentrations in the Megacity Beijing, Environ. Pollut., 182, 392-401, 2013b.

Shi, Z., Vu, T., Kotthaus, S., Grimmond, S., Harrison, R. M., Yue, S., Zhu, T., Lee, J., Han, Y., Demuzere, M., Dunmore, R. E., Ren, L., Liu, D., Wang, Y., Wild, O., Allan, J., Barlow, J., Beddows, D., Bloss, W. J., Carruthers, D., Carslaw, D. C., Chatzidiakou, L., Crilley, L., Coe, H., Dai, T., Doherty, R., Duan, F., Fu, P., Ge, B., Ge, M., Guan, D., Hamilton, J. F., He, K., Heal, M., Heard, D., Hewitt, C. N., Hu, M., Ji, D., Jiang, X., Jones, R., Kalberer, M., Kelly, F. J., Kramer, L., Langford, B., Lin, C., Lewis, A. C., Li, J., Li, W., Liu, H., Loh, M., Lu, K., Mann, G., McFiggans, G., Miller, M., Mills, G., Monk, P., Nemitz, E., O’Connor, F., Ouyang, B., Palmer, P. I., Percival, C., Popoola, O., Reeves, C., Rickard, A. R., Shao, L., Shi, G., Spracklen, D., Stevenson, D., Sun, Y., Sun, Z., Tao, S., Tong, S., Wang, Q., Wang, W., Wang, X., Wang, Z., Whalley, L., Wu, X., Wu, Z., Xie, P., Yang, F., Zhang, Q., Zhang, Y., Zhang, Y., and Zheng, M.: Introduction to Special Issue - In-depth study of air pollution sources and processes within Beijing and its surrounding region (APHH-Beijing), Atmos. Chem. Phys. Discuss., https://doi.org/10.5194/acp-2018-922, in review, 2018.

Song, S., Wu, Y., Xu, J., Ohara, T., Hasegawa, S., Li, J., Yang, L., and Hao, J.: Black carbon at a roadside site in Beijing: Temporal variations and relationships with carbon monoxide and particle number size distribution, Atmos. Environ., 77, 213-221, 2013.

Sun, J., Liu, L., Xu, L., Wang, Y., Wu, Z., Hu, M., Shi, Z., Li, Y., Zhang, X., Chen, J., and Li, W.: Key Role of Nitrate in Phase Transitions of Urban Particles: Implications of Important Reactive Surfaces for Secondary Aerosol Formation, J. Geophys. Res.-Atmos., 123, 1234-1243, 2018. 
Sun, Y., Jiang, Q., Wang, Z., Fu, P., Li, J., Yang, T., and Yin, Y.: Investigation of the sources and evolution processes of severe haze pollution in Beijing in January 2013, J. Geophys. Res.-Atmos., 119, 4380-4398, 2014.

Sun, Y., Du, W., Fu, P., Wang, Q., Li, J., Ge, X., Zhang, Q., Zhu, C., Ren, L., Xu, W., Zhao, J., Han, T., Worsnop, D. R., and Wang, Z.: Primary and secondary aerosols in Beijing in winter: sources, variations and processes, Atmos. Chem. Phys., 16, 8309-8329, https://doi.org/10.5194/acp-16-8309-2016, 2016.

Sun, Y. L., Zhang, Q., Schwab, J. J., Yang, T., Ng, N. L., and Demerjian, K. L.: Factor analysis of combined organic and inorganic aerosol mass spectra from high resolution aerosol mass spectrometer measurements, Atmos. Chem. Phys., 12, 8537-8551, https://doi.org/10.5194/acp-12-8537-2012, 2012.

Ulbrich, I. M., Canagaratna, M. R., Zhang, Q., Worsnop, D. R., and Jimenez, J. L.: Interpretation of organic components from Positive Matrix Factorization of aerosol mass spectrometric data, Atmos. Chem. Phys., 9, 2891-2918, https://doi.org/10.5194/acp-92891-2009, 2009.

Wang, J., Onasch, T. B., Ge, X., Collier, S., Zhang, Q., Sun, Y., Yu, H., Chen, M., Prévôt, A. S. H., and Worsnop, D. R.: Observation of fullerene soot in eastern China, Environ. Sci. Tech. Lett., 3, 121-126, 2016.

Wang, J., Zhang, Q., Chen, M.-D., Collier, S., Zhou, S., Ge, X., Xu, J., Shi, J., Xie, C., Hu, J., Ge, S., Sun, Y., and Coe, H.: First chemical characterization of refractory black carbon aerosols and associated coatings over the Tibetan Plateau (4730 ma.s.l), Environ. Sci. Tech., 51, 14072, https://doi.org/10.1021/acs.est.7b03973, 2017.

Wang, J., Wu, Y., Ge, X., Shen, Y., Ge, S., and Chen, M.: Characteristics and sources of ambient refractory black carbon aerosols: Insights from soot particle aerosol mass spectrometer, Atmos. Environ., 185, 147-152, 2018.

Wang, Q., Huang, R.-J., Cao, J., Tie, X., Shen, Z., Zhao, S., Han, Y., Li, G., Li, Z., Ni, H., Zhou, Y., Wang, M., Chen, Y., and Su, $\mathrm{X}$.: Contribution of regional transport to the black carbon aerosol during winter haze period in Beijing, Atmos. Environ., 132, 1118, 2016.

Wang, Y., de Foy, B., Schauer, J. J., Olson, M. R., Zhang, Y., Li, Z., and Zhang, Y.: Impacts of regional transport on black carbon in Huairou, Beijing, China, Environ. Pollut., 221, 75-84, 2017 a.

Wang, Y., Liu, F., He, C., Bi, L., Cheng, T., Wang, Z., Zhang, H., Zhang, X., Shi, Z., and Li, W.: Fractal dimensions and mixing structures of soot particles during atmospheric processing, Environ. Sci. Technol. Lett., 4, 487-493, 2017b.

Willis, M. D., Lee, A. K. Y., Onasch, T. B., Fortner, E. C., Williams, L. R., Lambe, A. T., Worsnop, D. R., and Abbatt, J. P. D.: Collection efficiency of the soot-particle aerosol mass spectrometer (SP-AMS) for internally mixed particulate black carbon, Atmos. Meas. Tech., 7, 4507-4516, https://doi.org/10.5194/amt-7-45072014, 2014.

Willis, M. D., Healy, R. M., Riemer, N., West, M., Wang, J. M., Jeong, C.-H., Wenger, J. C., Evans, G. J., Abbatt, J. P. D., and Lee, A. K. Y.: Quantification of black carbon mixing state from traffic: implications for aerosol optical properties, Atmos. Chem. Phys., 16, 4693-4706, https://doi.org/10.5194/acp16-4693-2016, 2016.
Wu, Y., Zhang, R., Tian, P., Tao, J., Hsu, S. C., Yan, P., Wang, Q., Cao, J., Zhang, X., and Xia, X.: Effect of ambient humidity on the light absorption amplification of black carbon in Beijing during January 2013, Atmos Environ., 124, 217-223, 2016.

Wu, Y., Wang, X., Tao, J., Huang, R., Tian, P., Cao, J., Zhang, L., Ho, K.-F., Han, Z., and Zhang, R.: Size distribution and source of black carbon aerosol in urban Beijing during winter haze episodes, Atmos. Chem. Phys., 17, 7965-7975, https://doi.org/10.5194/acp-17-7965-2017, 2017.

Wu, Z., Wang, Y., Tan, T., Zhu, Y., Li, M., Shang, D., Wang, H., Lu, K., Guo, S., Zeng, L., and Zhang, Y.: Aerosol liquid water driven by anthropogenic inorganic salts: Implying its key role in haze formation over the North China Plain, Environ. Sci. Technol. Lett., 5, 160-166, 2018.

Xie, C., Xu, W., Wang, J., Wang, Q., Liu, D., Tang, G., Chen, P., Du, W., Zhao, J., Zhang, Y., Zhou, W., Han, T., Bian, Q., Li, J., Fu, P., Wang, Z., Ge, X., Allan, J., Coe, H., and Sun, Y.: Vertical characterization of aerosol optical properties and brown carbon in winter in urban Beijing, China, Atmos. Chem. Phys., 19, 165179, https://doi.org/10.5194/acp-19-165-2019, 2019.

Xu, W., Han, T., Du, W., Wang, Q., Chen, C., Zhao, J., Zhang, Y., Li, J., Fu, P., Wang, Z., Worsnop, D. R., and Sun, Y.: Effects of aqueous-phase and photochemical processing on secondary organic aerosol formation and evolution in Beijing, China, Environ. Sci. Tech., 51, 762-770, 2017.

Yan, C., Zheng, M., Sullivan, A. P., Shen, G., Chen, Y., Wang, S., Zhao, B., Cai, S., Desyaterik, Y., Li, X., Zhou, T., Gustafsson, Ö., and Collett, J. L.: Residential coal combustion as a source of levoglucosan in China, Environ. Sci. Tech., 52, 1665-1674, 2018.

Yang, T., Guilin, H., and Zhifang, X.: Atmospheric Black Carbon Deposit in Beijing and Zhangbei, China, Proced. Earth Plan. Sc., 10, 383-387, 2014.

Zhang, Q., Alfarra, M. R., Worsnop, D. R., Allan, J. D., Coe, H., Canagaratna, M. R., and Jimenez, J. L.: Deconvolution and quantification of hydrocarbon-like and oxygenated organic aerosols based on aerosol mass spectrometry, Environ. Sci. Tech., 39, 4938-4952, 2005.

Zhang, Q., Jimenez, J., Canagaratna, M., Ulbrich, I., Ng, N., Worsnop, D., and Sun, Y.: Understanding atmospheric organic aerosols via factor analysis of aerosol mass spectrometry: a review, Anal. Bioanal. Chem., 401, 3045-3067, 2011.

Zhang, S., Wu, Y., Yan, H., Du, X., Max Zhang, K., Zheng, X., Fu, L., and Hao, J.: Black carbon pollution for a major road in Beijing: Implications for policy interventions of the heavy-duty truck fleet, Transport. Res. D-TR E, https://doi.org/10.1016/j.trd.2017.07.013, in press, 2017. 